\title{
How to combine descriptive and normative approaches in participatory urban planning: an experimental mixed-method implemented in the downtown district of Poznań, Poland
}

\begin{abstract}
This article presents a tool for reaching consensus in the participatory planning of the conversion and renovation of an urban space. It is based on the main assumption of combining descriptive and normative approaches in the actions of experts. It is an innovative way to strengthen the possibility of expert assessment in the decision-making process concerning desired spatial transformations. The authors hereof resorted to their own long-term experience when elaborating a tool that can easily support the selection of the optimal solution for maximizing benefits and minimizing outlay. The issues presented herein refer to the Central European context, which is characterized by a low level of social trust and by contentiousness in making joint decisions. The tool presented herein can contribute to participatory planning practice by enabling an expert to select solutions that meet the highest efficiency criteria on more objective grounds. It can be used to identify the convergent expectations of various social groups, thus facilitating conflict mitigation and arrival at a consensus. As a result, it can underlie the process of building social trust.

\section{Keywords}

Participatory urban planning - Central Europe - optimization methods • integrated management $\bullet$ expert assessment $\bullet$ decision making $\bullet$ descriptive approach $\bullet$ normative approach
\end{abstract}

(c) University of Warsaw - Faculty of Geography and Regional Studies

\author{
Bartosz Kaźmierczak $\mathbb{C}^{1}$, \\ Sławomir Palicki $\mathbb{C}^{2}$ \\ ${ }^{1}$ Faculty of Architecture, Poznań University \\ of Technology, Poznań, Poland \\ e-mail: bartosz.kazmierczak@put.poznan.pl \\ ${ }^{2}$ Department of Investment and Real Estate, \\ Poznań University of Economics and Business, Poland \\ e-mail: Slawomir.Palicki@ue.poznan.pl
}

\section{Introduction}

The issue of development and renovation of towns, and the participatory nature of the decision-making process concerning conversion of the urban tissue is specifically predetermined by the local characteristics of relevant Central European countries, which stems from their post-socialist past. Researchers from Western Europe or English-speaking countries may view this issue as dull, or even of secondary importance. Why such a view is not fully grounded is worth considering. The issue can be interesting, and the conclusions valuable, because the conversion of urban space in Central European countries constitutes a unique kind of experiment. The experiment shall consist in donning the attire of a traditional productive town following the development conditions of a rapidly growing Europeanization of the economy. Such an economy is mainly focused on mass consumerism and services, and exerts a deep impact, involving the deregulation of social relations and their market orientation in the context of a long-term management crisis. Such a state of affairs poses an ideological challenge requiring a change in thinking. This results from the logic of the process, which temporarily switches off market mechanisms, limits private ownership rights, and forces social welfare to be placed above the particular interests of different stakeholder groups (ed. Jałowiecki 1992; Nowak 2013).

The research problem analyzed herein concerns the decision-making process based on objective grounds, but taking account of social needs. It is an attempt to combine a mathematical, statistical or economic approach with sociology. This mathematical, statistical or economic approach is most often adopted by investor groups, or to some extent by the authorities. The sociological approach defines social paradigms in the context of making group decisions as well as areas of possible consensus and conflicts. A descriptive approach is a research method that describes typical human behavior in decisionmaking situations. Groups composed of inhabitants, local leaders or urban activities most often represent the descriptive approach, because people usually fail to adopt one, optimum behavior style (Bell, Raiffa \& Tversky 1988).

The purpose of these studies is to define the process of arriving at the optimum decision - i.e. rendering, on an equal basis, the highest benefits in view of all the ideas proposed by different groups. Combining both approaches in the tasks inherent in the role of an expert within the participatory urban planning process is the authors contribution into new knowledge (Fig. 1).

This article is more than just a description of how to solve conflicts arising from urban projects. It is also an attempt by the authors to develop an experimental mixed-method of assessment helping to prioritize proposed ideas. The paper presents a new approach to problem-solving and decision-making within participatory urban planning process. Using the case study of the 


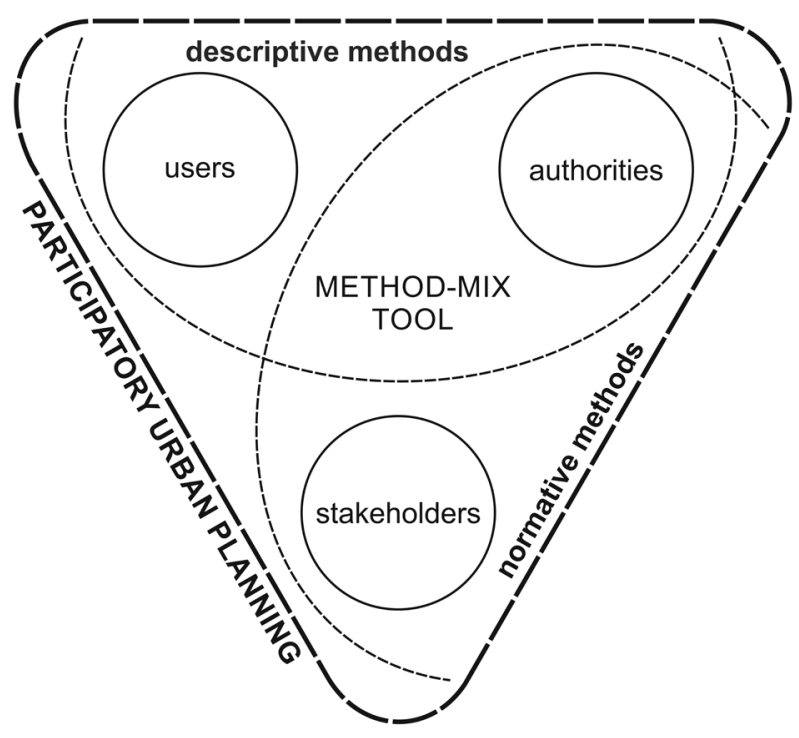

Figure 1. The idea of combining descriptive and normative methods in participatory urban planning

Source: authors' elaboration

revitalization of Śródka district in the city of Poznań, the authors implemented the invented tool to conduct an experiment. ${ }^{1}$

Literature review: finding a balance between descriptive and normative approaches in participatory urban planning

Responding to the real, identified needs of local communities, both while preparing planning documents and development strategies, and during their implementation, are important factors underlying the process of building social trust and ensuring social satisfaction. However, it is a fully participatory process that may not be possible to a satisfactory degree. This will primarily apply to all stages of the planning process - from development programs and activities, through their implementation, to monitoring. The socialization of the process increases the level of social acceptance of investment projects, and thus in subsequent stages increases social and economic effectiveness and the efficiency of actions taken (Durka 2011; Boryczka et al. 2017). Social communication between all stakeholders is a prerequisite for a successful participatory planning process. Such communication is based on a two-way flow of information inspiring all stakeholders to participate actively in this process (Kot 2003).

Social participation shall be understood here as direct and long-term citizen engagement in and impact on the local decisionmaking process, particularly in the area of public policies and services. Their social impact is above all perceived in the context of changes to local services, products or political decisions resulting from resident petitions and requests. It is important that representatives of possibly the most common urban diversified group of inhabitants' be engaged in the decision-making process because they have an in-depth knowledge of local needs,

${ }^{1}$ Since 2008, the authors have been actively involved in activities supporting the stakeholders of the renewal process in Sródka. As part of their expert work, they participated in formulating the principles of the Public Space Charter - a document that largely draws from the experience of working in the area covered by the revitalization program. Together with the team, they carried out a comprehensive evaluation of the first stage of the revitalization program, and in later years they repeatedly engaged in ad hoc projects aimed at supporting the local community of residents and entrepreneurs of Śródka with their knowledge. The authors of this article contributed a number of publications and design studies of a conceptual and implementation nature to the state of research on the transformations of this Poznań district. opportunities and resources (Przywojska 2018). Unfortunately, the most frequent practice is to present developed design solutions, on which social groups are then consulted. This practice is usually defended by arguing that there is time pressure from procedures for applying for EU funds. As a result, the term "participatory planning" becomes an empty phrase used to acknowledge that consensus has been reached in social negotiation (to qualify for funds) (Miessen 2010; Kazepov, Scott \& Silver 2010). Therefore, the voice of local communities is rarely fully taken into account and rarely has any impact on the decision-making process, especially at the level of program implementation. Participatory planning, furthermore, facilitates drafting local communities' programs of activities as early as at the design stage (i.e. via the placemaking process) and supports the development of local partnership cooperation networks to improve the chances of successful implementation of specific solutions (Martyniuk-Pęczek \& Rembarz 2016b).

The social network is one of those theoretical perspectives that allow to define the rules of joining forces in the process of city development or revitalization. Such networks take a specific form in public zone management, namely network governance, which can be defined as a way of planning and implementing public policies by creating a network of relationships between authorities, entrepreneurs and key social entities (Klijn \& Skelcher 2007). The main idea of such networks is to engage relevant key players experts with the appropriate resources and know-how to achieve the set goals. Due to their social contribution, local community researchers list a number of mechanisms for transposing local network structures into institutional effectiveness (Theiss 2013).

The experts' side in the participatory planning process should be represented by professionals of complementary competences in a variety of scientific disciplines (Forester 1999). The role of experts is to inspire the creation or mobilization of certain activities within the premises of a given area by, among others: stimulating systemic cooperation within the framework of participatory urban planning; supporting the conceptions of micro-local strategies, visions and ideas in the area of space development or revitalization; and also the acquisition of knowhow within good professional practices.

Socialization should not be put on self-governments only. Socialization of the planning process needs to be based on the fact that all planning participants are able to properly take part in the process. In particular, they ought to learn from one another. The authorities get to know about the needs of the community at meetings with community members, the users of urban spaces learn about the planning rules, and investors become familiar with how to formulate expectations (Meléndez \& Parker 2019; Przywojska 2019). Experts who show participants how to communicate with each other, building mutual trust and pushing aside prejudices, can be helpful (Fig.2).

As a rule, participatory urban planning is embedded in a descriptive approach, based on discussions and deliberative understanding of decision-making. The descriptive (behavioral) approach, although widespread in social sciences, including organization and management theory, is primarily of an explanatory nature. It clarifies the essence of making a decision, but does not recommend what decision to make. That is why many authors paid attention to the need to support decisions using a normative (analytical) approach (Bell, DE, Raiffa, H \& Tversky, A 1988, Dabrowski, A, Schumann, A \& Woleński, J 2015).

The key tool supporting social choice is decision-making analysis. Expert decision-support methods were developed in the 20th century. A leading representative of the relational theory of welfare, K. J. Arrow, mathematically proved already in 1951 that society is incapable of behaving like a rational economic decisionmaker (Arrow 1963). On the other hand, H. Simon showed in his 


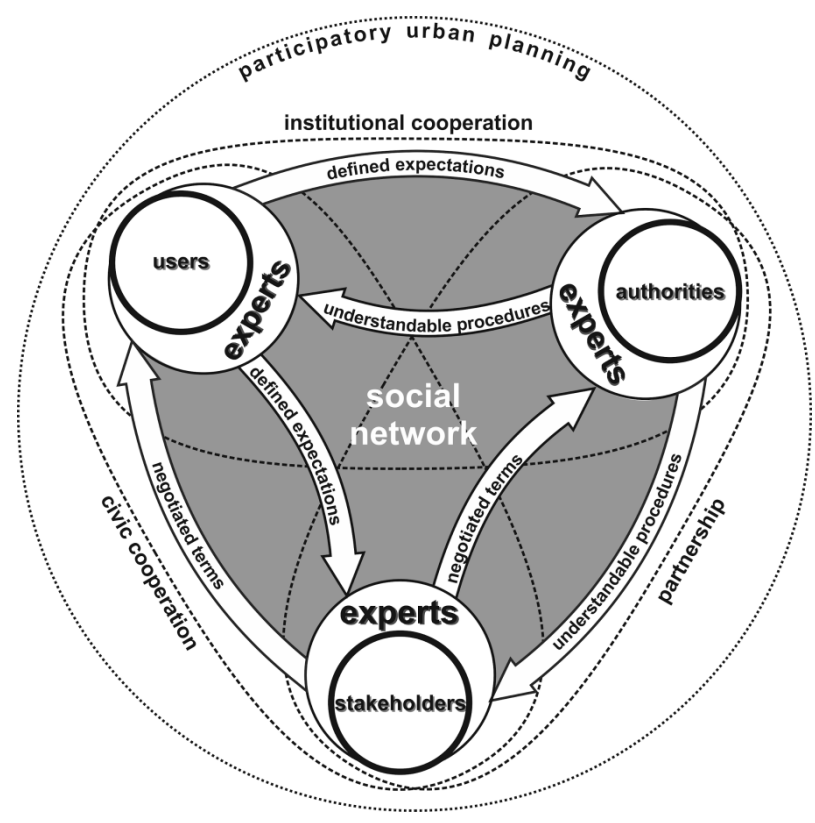

Figure 2. The role of experts in participatory urban planning Source: authors' elaboration

concept of limited rationality that the alleged main goal of the decision-maker in the form of utility maximization is unrealistic, due to the limited cognitive capabilities of the decision-maker. In multifaceted alternatives, people are limited by the cognitive abilities of their minds and because they base their choices on assessments of adaptation on only a few characteristics of these alternatives (Simon 1955). Therefore, absolute rationality, which is a priori research, is burdened with criticism. A posteriori rationality competes with it, somehow resulting from Simon's theory of limited rationality. "The concept of a posteriori rationality is adapted to the conditions of adjustment, with advances in collaboration being achieved through the agreement of the means of action and the experience gained by the parties during the process. So it is a cooperative model focused on adaptive experimentation" (Śleszyński 1990). The achievement of an empirical optimum in itself is not the purpose of certain social group (stakeholder) searching, but, ultimately, satisfaction is the de facto equivalent.

This distinction between the concept of absolute and limited rationality refers to methods divided into normative and descriptive (behavioral) decision-making (Larichev 1999). This does not mean, however, that the descriptive model does not use any formal apparatus or that the normative approach completely abstracts from description. Descriptive models reflect reality without establishing a priori correctness patterns: they provide knowledge about the problem. Descriptive methods strive to perceive phenomena holistically, perceiving in them connections between smaller elements in a larger whole. Therefore, they postulate an interdisciplinary perception of the subject of the study. The descriptive approach resigns from the top-down assumption that the most important factor dominates the other components. The leading idea here is to look for interactions, interdependencies, a network of causes and effects, and not to identify the most important factor. This approach makes it possible to recognize qualitative factors that are difficult to measure or factors for which there is a problem with an unambiguous assessment of intensity. Descriptive methods take into account the multiplicity of goals and the variety of criteria for assessing the degree of meeting these goals, giving the opportunity for interactive development of cooperation between social groups (stakeholders) involved as parties to the decision-making situation. Descriptive decision-making theory has an explanatory character, answering the question of how decisions are made in practice, and not what they should be. Nowadays, the descriptive approach has been associated with systemic analysis, which focuses on the analysis and evaluation of decision alternatives in complex situations. Such a bundled approach is sometimes referred to as prescriptive, which is "implementing of pure theory into practice" (Raiffa 1994; Stachowiak 2002).

The expert's role is to identify the decision-making problem in an analytic system, to define the alternatives and the assessment criteria for these alternatives in accordance with the decisionmaking problem, to draw up a decision matrix or tree, to assess and rank the alternatives. The expert in such a decision-making system has his own space and makes his assessments according to the alternatives and criteria relevant to the individual decisionmaking problem (Basheleishvili 2020). Many authors have pointed to the possibility of solving decision problems in the area of local and regional development with various normative methods in the field of graph theory, system analysis, multi-criterion, multi-level or multi-purpose analysis (Roy 1990; Langendijk 2001; Wota 2008; Kobryń 2014; Prusak \& Stefanów 2014; Łaszkiewicz 2016; Grabowski 2019).

\section{Case study reflecting experimental mixed-method}

Śródka is a small housing estate on the border of Poznan downtown area. The social, economic and spatial changes it has undergone are of interest to all the stakeholders that view revitalization as an important regeneration process of degraded urban fabric. Since 2006, Śródka has been included in the local revitalization program. This small housing area has since become the core of research and a case study in respect of the implementation of revitalization activities prescribed in the aforementioned revitalization program. Opinions concerning the assessment of the effects of Śródka revitalization vary. Many researchers are critical of the effects of the activities undertaken within the framework of the program in 2006 (Kaźmierczak et. al. 2011) pointing out that they resulted in increased rents ${ }^{2}$ and pushed out the financially fragile inhabitants from the area (Palicki 2013). Nevertheless, we cannot overlook the positive spatial changes that have improved the aesthetics of development and public space or increased the functional attractiveness of the district owing to the opening of the Interactive Centre for the History of Ostrów Tumski. The process, furthermore, increased the awareness of the inhabitants and the entrepreneurs living and operating in Śródka in respect of the district's contribution to creating the image of Poznań.

Activities undertaken to revitalize degraded areas - in particularly those located in the central part of the city - must account for certain adverse phenomena inherent in increased attractiveness of an area under revitalization. The increased popularity of a place where many cultural events are organized translates into improved visual aspects of the urban space, which then becomes a major hub for leisure and entertainment, and this can lead to conflicting social needs of particular groups. In the case of Śródka, the stakeholders have many times successfully managed to balance the interests of respective groups, thus preventing any conflict escalations and loosening of the social bonds that have been established with so much care and engagement.

Escalating dissatisfaction of the entrepreneurs operating in Śródka district concerned the thus-far-unsolved problem of transit through the housing estate and poor organization of parking

${ }^{2}$ The pilot revitalization program in Śródka led to partial gentrification of the district. 
options. The second conflict developed unexpectedly when the owners of previously renovated tenement houses demanded that the traffic lights operator that had used the facades of the houses for installing lighting fixtures should reimburse the owners part of the renovation costs. Because the operator did not have any concluded agreements in this respect, it refused to pay any compensation to the tenement house owners. As a result they refused to have the light fixtures installed on their building facades. Due to the conflict, the spatial attractiveness of Śródka declined and, as per the claims of local entrepreneurs, translated into decreased revenue from business operations, mainly from the catering business. To resolve the conflict and to agree on the right solution in the best interest of the inhabitants of Śródka district, it was necessary to involve the municipal authorities. The authorities delegated appropriate experts to develop a solution to the dispute in a manner that would tighten the human bonds and strengthen mutual trust.

The purpose of the descriptive part was to generate ideas for solving current problems in the area covered by revitalization. It was an inclusive, participatory activity, using a moderated discussion and brainstorming. The descriptive approach allows complex phenomena to be captured that would be difficult to observe using normative methods. Knowledge of the problems related to the functioning of enterprises in the context of district development is closely related to a specific group of people - the entrepreneurs operating in a given area. They are the ones who have detailed information about what is happening in the vicinity. The use of a descriptive tool - a moderated discussion, allows the state of affairs to be examined, the studied group's attitude to problems to be demonstrated, and compliance and differences in the perception of individual phenomena to be emphasized (Sutton \& Kemp 2006).

The heuristic technique of brainstorming gives the opportunity to work out solutions when the group does not have adequate knowledge on the subject of the problem. Such a heuristic becomes a procedure that can achieve effective, though imprecise solutions to complex problems (Kahneman 2012). Therefore, it is possible to generate a number of solutions that, although they will not be precise answers to the question asked, will nevertheless create a set of certain ideas that arose as a result of a collective effort to find common solutions.

In the light of the decision theory, three types of decisions are distinguished: decisions in conditions of certainty, where each decisive action leads to a specific and known result, decisions in risk conditions, where each possible action is assigned a probability distribution of a specific result from a set of possible outcomes, and decisions in conditions of uncertainty. These last are undertaken without the knowledge of the probability distributions of the corresponding results (Grzybowski 2012).

Decision-making in the context of a participatory model of urban planning should be considered as the second type. This is due to the specificity of revitalization processes, which require the development of an individual problem-solving model in each area covered by such a process. Under conditions of risk and partial uncertainty, the decision-maker may make a mistake in assessing the rationality of the adopted solution (Tversky \& Kahneman 1981). Such rationality can be achieved by using normative techniques.

The main idea of this research was to develop a tool that might optimize the process of selecting the most beneficial solutions from a set of available options using the Pareto Principle and graph analytical techniques. The 80/20 Rule, proposed by Vilfredo Pareto (Juran 2008), an economist, has become an efficient problem-solving tool based on prioritization of problems. Under the Pareto Principle, $20 \%$ of the analysis input groups generate $80 \%$ of profits (Kaczorowska \& Staniec 2019). The $80 / 20$ Rule allows us to define the main directions of activities to be undertaken in view of the maximum results expected. We must, however, remember that the aforementioned proportions are to some extent flexible. The Pareto Principle still remains the most frequently used tool in quality management. Quality is improved by identifying the frequency and seriousness of potential quality problems (Cichoń \& Walecko 2017). It allows users to prioritize the activities and, when working out their plan, to increase the efficiency of such activities by focusing on troubleshooting, which in turn enables us to eliminate those problems that most prevent us from obtaining the intended effect. The Pareto Principle is a universal technique that can efficiently underlie decision-making. It is widely used in identifying the main causes of problems and developing plans of corrective actions.

Graphs theory has an established role in mathematics as an efficient tool in a variety of disciplines: in chemistry and genetics, linguistics and sociology, electronics and computer science, as well as geography and architecture (Wilson 1996). Trees, being hierarchical structures in a graphical form, are an important part of graphs theory. This article presents the methodology of selecting the most efficient set of elements by means of a directed graph, being a tree, and next by means of a hypergraph.

Figure 3 presents the procedure based on an optimization method that is clearly divided into a descriptive and a normative part, which are closely related to each other. As a result of all undertaken research activities, the following step-by-step procedure (applied to a case study) was proposed:

Phase 1) Defining the strategic goal (moderated discussion)

Phase 2) Diagnosis of the situation - construction of the "opening balance" (using strategic SWOT analysis)

Phase 3) Active and free generation of ideas (brainstorm heuristic technique)

Phase 4) Analysis and classification of generated ideas resulting in the definition of strategy, strategic goals and activities (the use of grouping methods according to the thematic/material criteria, semantic analysis, analysis of similarities and differences)

Phase 5) Determining the hierarchical structure of the situation in the form of a multi-level diagram/graph (final definition of the superior-subordinate relationships between the main goal, strategies, strategic goals and activities - See fig. 4)

Phase 6) Construction of a graph of functional relationships between processes, taking into account the directions and strength of influences between individual activities and strategic goals in the area of strategy. It should also include an analysis of the possible impact of a given action on all strategic goals within all defined strategies - See fig. 5 (deductive procedure using cause-and-effect analysis)

Phase 7) Selecting actions constituting main factors in enabling the achievement of strategic goals (final decisions on the order and scope of the actions to be implemented should be based on the Pareto Principle; may be also supported by multicriterion analysis, system analysis) - See tables under graph in fig. 5

Phases 1-3 use a descriptive (behavioral) approach and phases 4-7 use a normative (analytical) approach to solve complex local problems. The Mixed-method exploits the advantages of both approaches, which makes the entire decision-making process more transparent and objective. The role of the expert is crucial during the implementation of the entire procedure discussed.

\section{Workshop: descriptive approach}

To make optimal use of the time individual entrepreneurs could devote to participating in the workshop, its preliminary priority assumptions were worked up in advance. It was agreed that the workshop would focus on the main task, namely on making the participants aware that everyone would make their 


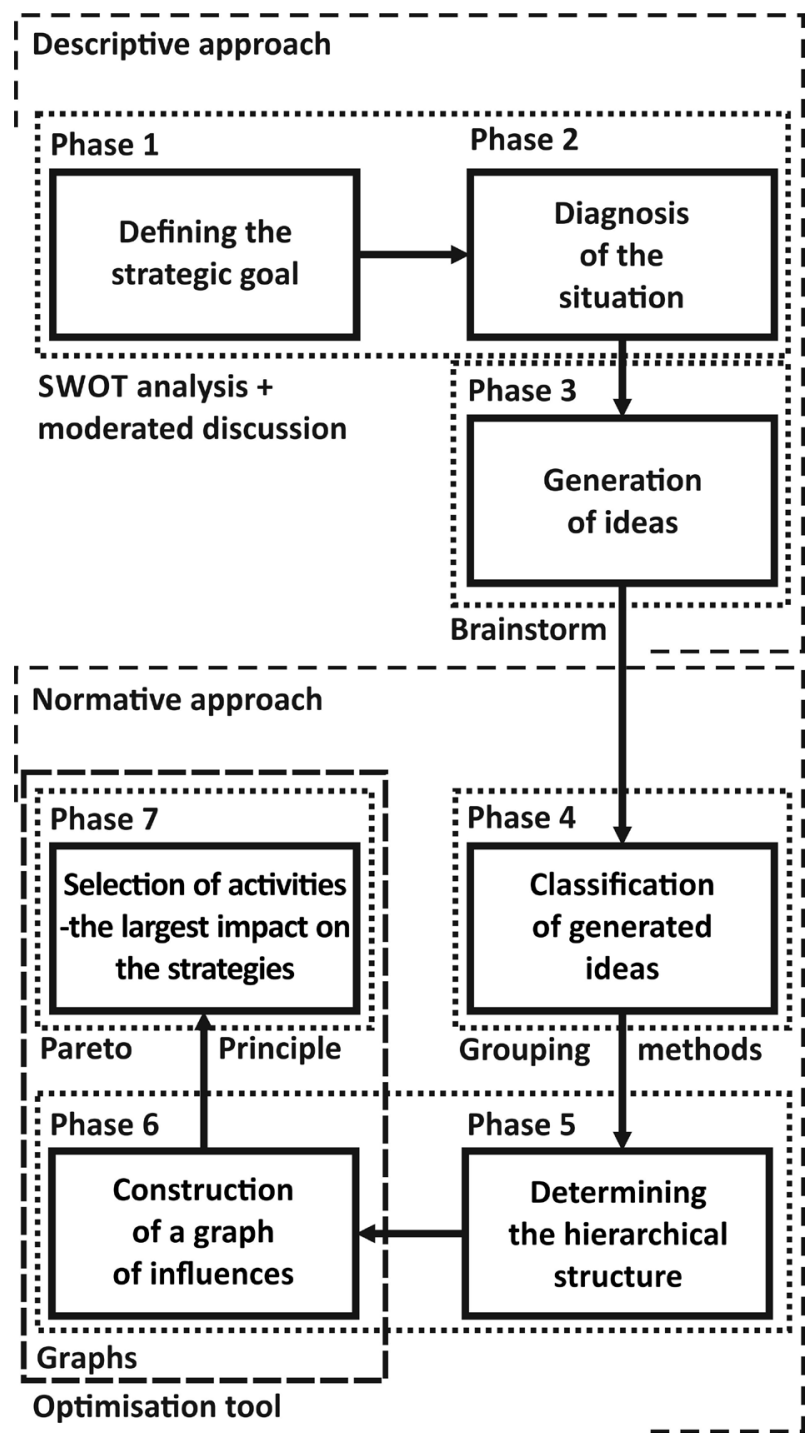

Figure 3. The principle of combining descriptive and normative approaches using the optimization

Tool Source: authors' elaboration

own contribution in the process of introducing changes because the resultant common welfare would be in our common best interest. The meeting was scheduled for three hours; the planned workshop was divided into two thematic groups: diagnosis listing the problems and directions of changes, during which part of the workshop the participants searched for possible solutions to the reported problems. The main idea was to obtain the optimally representative solutions proposed by different groups of stakeholders; the idea was, however, extended by the representatives of the housing-estate board. The board wanted to make the entrepreneurs realize what the features of the space in which they run their business operations were. Running a business in Śródka district means that one should not only draw the benefits from the location but also bear liabilities towards the local community as well as liability for the historical and cultural assets of the place.

The first part of the workshop started with two short presentations by the experts (an architect/urban planner and an economist) chairing the event. After the introductory part, the participants were asked to report problems that for them directly translated into reduced income - phase 1. Next, the chairmen moved to classifying the comments made using a standard marketing evaluation method, i.e. SWOT analysis - phase 2.

The experts then asked to assign weights using a scale of $1-5$, to the individual components of the assessment. Weights were proposed spontaneously according to the principle that participants in the discussion pointed out the values and the rest of the group members either agreed or discussed with proposals. As the conditions submitted for assessment were in a sense agreed upon by the group at an earlier stage, the vast majority of factors were considered as key problems.

The second part of the workshop was dedicated to searching for solutions that, in view of the reported problems, could positively affect business operations of Śródka entrepreneurs - phase 3. The weight assigned was to make the participants realize that the ideas need to be expressed more precisely and the solutions proposed within the SWOT analysis need to be narrowed down. The participants were free to come up with ideas, which were not moderated by the chairmen. The following ideas were proposed (with the observance of their sequence):

1. Provide a system of continuous and distinctive lighting to clearly demarcate the entire length of the Royal-Imperial Route (the Old Market Square, Chwaliszewo, Ostrów Tumski, Śródka).

2. Compile a guide book about Śródka that would be continuously in stock at any tourist information office in Poznań.

3. Use a mural in promotional and informative materials/ leaflets.

4. Use slogans including the district name, i.e. Śródka, "Śródka - the smallest town in Poland", "Śródka - the place of the origins of Poland".

5. Make the historical sites in Śródka available to visitors, including sacral facilities.

6. Create a new sign or symbol of the place (following the example of the mermaid in Copenhagen).

7. Stress the uniqueness of what Śródka district has to offer, intended for individuals but not for masses (quiet nights, busy days).

8. Attract pedestrians, yet leave and clearly delimit the car parking spaces.

9. Remove transit traffic.

10. Create a formal "incentive" that will invite cyclists and pedestrians from the riverside.

11. Enhance what Środka has to offer by unifying it with Ostrów Tumski and coordinating joint activities.

12. Strengthen the social impact of the day of Saint Peter and Paul, the holy patrons of Poznan (as an alternative or supplementary event to St. Martin's feast day).

13. Coordinate - to a larger extent than before - the organization of events and celebrations in church, culinary and cultural events that take place in Śródka.

14. Allow street stall sales (fairs, weekend sales, flea markets or antique fairs [china, clocks], militaria fairs).

15. Open a car park near the school for deaf children.

16. Bring more life to the district, via restaurant outdoor patios.

17. Create tourist-friendly infrastructure in the form of small architecture such as benches, rubbish bins and information boards (maps / information boards / road signs / tourist information about facilities) with the support of the Poznan Local Tourist Organization (PLOT).

18. Encourage new investors - open up to new original ideas.

19. Create an attractive image of the district on social media - a quasi-official forum for the exchange of opinions and a form supporting the business interests of the entrepreneurs 
MISCELLANEA GEOGRAPHICA - REGIONAL STUDIES ON DEVELOPMENT

Vol. $25 \cdot$ No. 3 • 2021 • pp. 145-154 • ISSN: 2084-6118 • DOI: 10.2478/mgrsd-2020-0057

Table 1. Summary of comments reported, as SWOT analysis

\begin{tabular}{|c|c|c|c|}
\hline \multicolumn{2}{|r|}{ STRENGTHS } & \multicolumn{2}{|r|}{ WEAKNESSES } \\
\hline \multicolumn{2}{|c|}{ weight } & \multicolumn{2}{|c|}{ weight } \\
\hline 5 & historical area & 5 & lack of information about the place and its attractions \\
\hline 5 & integration of business entities/fair competition & 5 & darkness in the evening/lack of proper street lights \\
\hline 4 & $\begin{array}{c}\text { catering zone } \\
\text { [offer clustering: note by author] }\end{array}$ & 5 & inaccessibility of attractive sacral and educational facilities \\
\hline 3 & coziness & \multirow[t]{2}{*}{5} & \multirow{2}{*}{$\begin{array}{c}\text { poor legibility of the urban layout/architectural composition/ } \\
\text { separation, interrupted transport route/lack of integration } \\
\text { with Ostrów Tumski }\end{array}$} \\
\hline 3 & location & & \\
\hline \multicolumn{2}{|r|}{ OPPORTUNITIES } & \multicolumn{2}{|r|}{ THREATS } \\
\hline \multicolumn{2}{|c|}{ weight } & \multicolumn{2}{|c|}{ weight } \\
\hline 5 & combination of the offer of Śródka and Ostrów Tumski & 5 & incoherent investment policy \\
\hline 5 & $\begin{array}{c}\text { opportunity to work up a common strategy of } \\
\text { development, instead of separate tourist and cultural } \\
\text { offers }\end{array}$ & 5 & $\begin{array}{l}\text { no cohesive thinking about Śródka shared by a variety of } \\
\text { stakeholders (inhabitants, entrepreneurs, local politicians, } \\
\text { the municipal authorities, the Church), in this lack of } \\
\text { coherent spatial planning policy }\end{array}$ \\
\hline \multirow[t]{3}{*}{5} & local media publicity & 5 & $\begin{array}{l}\text { traffic jams/transit traffic every day in Śródka district (in the } \\
\text { morning and at about } 4 \text { pm) - in this, many collisions and } \\
\text { accidents at Śródka Roundabout }\end{array}$ \\
\hline & & 3 & $\begin{array}{l}\text { organization of municipal events that prevent access to } \\
\qquad \text { Śródka }\end{array}$ \\
\hline & & 3 & competition - other districts of the city (e.g. Jeżyce or Wilda) \\
\hline
\end{tabular}

Source: compilation by authors

seated in Śródka in cooperation with the Board of the Housing Estate and the Society of the Friends of Śródka "Śródeja", etc.

Data analysis: normative approach

The main idea of the research was first to evaluate the proposed ideas and to classify them in compliance with goal priorities, and then to identify their mutual interrelations to choose the most crucial element of the set.

The first stage of the research involved classifying the proposed ideas into sets with such criteria in mind as: level of detail/generality, and type of activities to be undertaken (soft/hard) - phase 4. A group of ideas representing the elements of the main set were divided into sub-sets and a relevant graph structure was worked up. Because we could connect any two vertices by exactly one path, the developed graph can be called a tree. (Wilson 1996). The ideas that had been least concretely formulated were assumed to be the basic sets defining only the nature of the undertaking. They are neither specific activities nor have been deemed as targets of goal strategies (color-marked sets). The graph presented below (fig. 4) shows how the ideas were structured to represent the division into the ideas that were the most and the least specific. The main goal - although not explicitly formulated during the workshop - was to increase the attractiveness of Śródka district. The next level in the assessment procedure was to identify ideas that would make it feasible to meet the main goal and that comprise a number of more detailed solutions, thus creating a hierarchical structure - phase 5 . Of all such ideas, the experts selected two that can define the main strategies:

I. "new investors - opening up to new original ideas"

II. "tourist-friendly infrastructure..."

The selection was based on the fact that the remaining options directly concerned either soft forms - organizational activities, or infrastructure. The proposed ideas were classified into two strategies and sub-divided into sub-groups by topics. In each thematic sub-group, it was possible to choose an idea that determines the strategic goal for the activities of the sub-group. With regard to the previously proposed research procedure, the sub-groups should be equated with the strategic goals and the activities subordinated to them. The following groups of ideas were allocated to strategy I:

I.A. "to create a unique offer for Śródka district, intended for individuals but not for masses (quiet nights, busy days)"

I.A.a. "to integrate the organization of events/festivities"

I.A.b. "to create a social media profile"

I.A.c. "to allow street stall sales"

I.A.d. "to enhance what Środka has to offer by cooperation with Ostrów Tumski"

I.A.e. "to popularize/strengthen the social impact of the day of Saint Peter and Paul, the patron saints of Poznań"

I.B. "to compile a guide book about Śródka attractions and sights"

I.B.a. "to make the historical sights and sacral facilities available to visitors" 


NEW INVESTORS - OPENING UP TO NEW ORIGINAL IDEAS

I.A.

to create unique offer of Śródka district, intended for individuals but not for the masses (quiet nights, busy days)

I.A.a to integrate the organisation of events/festivities

I.A.b to create a social media profile

I.A.C allow street stall sales

I.A.d to enhance what Środka has to offer by cooperation with Ostrów Tumski

I.A.e to popularise/strengthen the social impact of the day of Saint Peter and Paul, the holy patrons of Poznan

I.B.

to compile a guide book about Śródka attractions and sights

I.B.a to make the historical sights - sacral facilities available to the visitors

I.B.b to use the 3D mural in the promotions

I.B.C to promote slogans
II.

TOURIST-FRIENDLY INFRASTRUCTURE

II.A.

to create characteristic sign/symbol of the place

II.A.a to provide a system of continuous and distinctive lighting to clearly demarcate the entire length of the Royal-Imperial Route

II.A.b to create a formal 'incentive' that will invite cyclists and pedestrians from river side

II.B.

to attract pedestrians, yet leave and clearly delimit the car par places

II.B.a to bring more life to the streets owing to restaurant outdoor patios

II.B.b to remove the transit traffic in Środka district

II.B.C to open a car park near the school

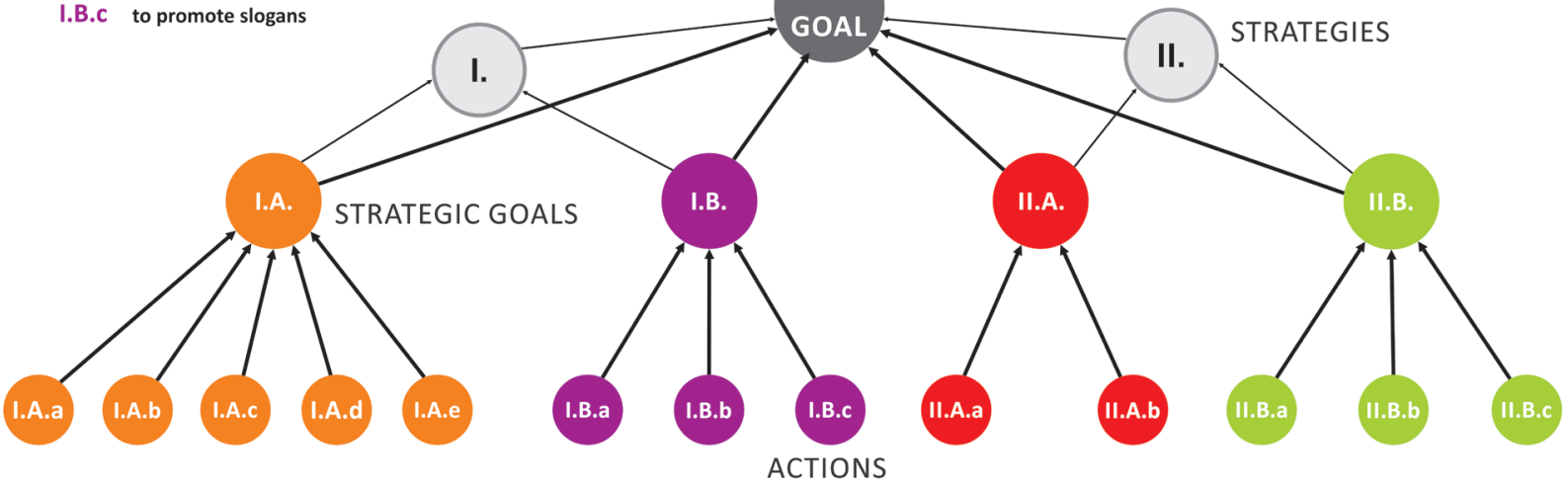

Figure 4. Ideas Classification Scheme Source: authors' elaboration

I.B.b. "to use a 3D mural in promotions"

I.B.c. "to promote slogans"

The following groups of ideas were allocated to set goal II:

II.A. "to create a new sign/symbol of the place"

II.A.a. "to provide a system of continuous lighting demarcating the entire Royal-Imperial Route"

II.A.b. "to create a formal 'incentive' that will invite cyclists and pedestrians from the riverside"

II.B. "to attract pedestrians, yet leave and clearly delimit the car parking spaces"

II.B.a. "to bring more life to the streets via restaurant outdoor patios"

II.B.b. "to remove the transit traffic through Środka district"

II.B.c. "to open a car park near the school"

For the further assessment process the complementarity of the proposed ideas was verified. Following the Pareto Principle (the $80 / 20$ Rule) the implementation of $20 \%$ of those ideas may render $80 \%$ of the desired effects (Hamrol \& Mantura 1999). Therefore, it would be fully grounded to identify those activities that are of key importance for reaching the strategic goals - to which groups of ideas were allocated - because such an approach would speed up the realization of the set goal (Fig. 5).

Strategies I and II were deemed to be passive vertices that added no discernible value, and were disregarded in further analysis. Each strategy goal was assigned the same weight. Following the adopted methodology, links other than those following from the assumed hierarchy were selected. The vertices were linked by providing activities that worked in a complementary way to meet the goals of various strategies at once.

A diagram was worked up to clearly show the activities that were correlated with one another at the vertical level and which at the same time could facilitate reaching the goals of other groups of ideas - phase 6 . As a result, a new graph of interdependencies was drawn up. It explicitly presents the ideas of key importance - nodes for the goals pursued in other groups of ideas - phase 7. It was concluded from the analysis that two activities affect the reaching of the goal of II.A., eight activities affect the reaching of the goal of I.A., and six activities affect the reaching of the goal of I.B. and II.B. Analyzing the role of respective activities, it can be concluded that II.A.a, II.A.C and II.B.a affect three different goals. From the analysis it follows that implementing II.A.a exerts the largest impact on the set goal because it makes up $50 \%$ of activities within II.A., $16.7 \%$ within II.B. and $16.7 \%$ within I.B. Therefore, "implementing a continuous lighting system demarcating the entire Ostrów Tumski and Śródka" is the activity that in accordance with the Pareto Principle shall exert the largest impact on reaching the pursued goals.

\section{Results and discussion}

Summing up the research part of the article, the stakeholders/ participants should first of all solve the Royal Route lighting issue. Next, they should focus on activities II.B.a and I.A.C. These could additionally support the implementation of the goals under I.B and II.A and initiate the works intended to meet the goal under I.A. Implementing the top priority ideas first will allow 

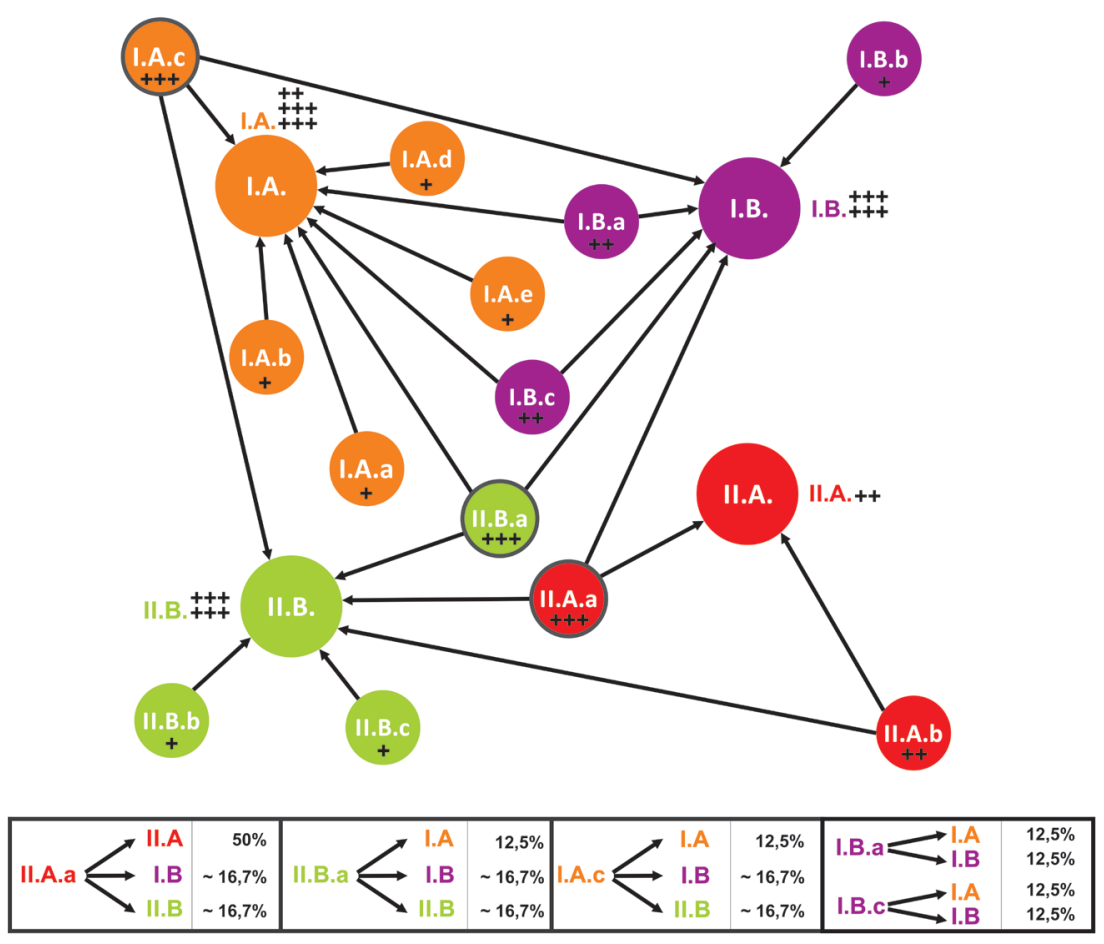

\begin{tabular}{|c|c|c|c|c|c|c|c|}
\hline II.A II.A.b & $\begin{array}{l}\mathbf{5 0} \% \\
\mathbf{5 0} \%\end{array}$ & II.B & $\begin{array}{l}\sim 16,7 \% \\
\sim 16,7 \% \\
\sim 16,7 \%\end{array}$ & $\overbrace{\text { I.A }}^{\text {I.A.A.b }}$ & $\begin{array}{l}12,5 \% \\
12,5 \% \\
12,5 \%\end{array}$ & I.B $\underset{\text { I.B.B.c }}{\text { I.B.a }}$ & $\begin{array}{l}\sim 16,7 \% \\
\sim 16,7 \% \\
\sim 16,7 \%\end{array}$ \\
\hline & & - Il.A.a & $\sim 16,7 \%$ & & $\begin{array}{l}12,5 \% \\
12,5 \%\end{array}$ & I.B $\longleftarrow \| . B . a$ & $\sim 16,7 \%$ \\
\hline & & $\| . B \longleftarrow$ I.A.C & $\sim 16,7 \%$ & I.A I.B.a & $\begin{array}{l}12,5 \% \\
12,5 \%\end{array}$ & I.B $\longleftarrow$ II.A.a & $\sim 16,7 \%$ \\
\hline & & & & $\mathrm{I} . \mathrm{A} \longleftarrow$ II.B.a & $12,5 \%$ & $\mathrm{I} . \mathrm{B} \longleftarrow \mathrm{I} . \mathrm{A} . \mathrm{C}$ & $\sim 16,7 \%$ \\
\hline
\end{tabular}

Figure 5. Map of interdependencies between strategic goals and activities Source: authors' elaboration

the stakeholders to optimally use their limited organizational and financial resources.

The experimental mixed-method presented by the authors aims to classify the proposed ideas in an orderly manner and to identify logical interconnections between them. It shall, however, be assumed that during the implementation of relevant activities new interdependencies may arise, i.e. new ideas that have failed to be taken into account at a relevant stage by the experts. According to the local needs diagnosed in Śródka district the case study was based on the criterion of the effectiveness of implemented actions. It is possible to imagine different potential criteria for selecting solutions:

- costs, sources of financing,

- $\quad$ continuity, the ability to maintain the effects,

- conflictogenicity / compromise / consensus,

- $\quad$ time horizon.

Only a full assessment will allow for the most accurate and objective development of the priorities of the planned activities. Further assessment criteria may identify other factors - barriers and threats inherent in the implementation of ideas. Nevertheless, from the perspective of making joint decisions and creating strategies based on the maximum effect, the purpose of the research will be met with the minimum outlay. The classification made with the application of the optimization tool has successfully selected the top priority undertakings out of all the ideas proposed at the workshop on relatively objective grounds.

\section{Conluding remarks}

Successful cooperation between all the stakeholders in the participatory urban planning is founded on openness, engagement and will to cooperate. A change to the model described as DAD: Decide-Announce-Defend into EDD Engage-Deliberate-Decide (Selle 2011) positively fosters public dialogue and increases the involvement of local communities in the undertaken activities. The bottom-up process is facilitated with such methods as "adaptation and control," which require the adjustment to new conditions created via a change in attitudes and behavior and which assure capabilities necessary to implement the desirable changes. Hence, the process propagates the best model of participatory planning, understood as active actors of changes and not only as passive bodies with certain needs and preferences (Vischer 1985; Carmona et al. 2010).

The value of the studies consists in highlighting the unbiased nature of experts' assessment and the need to integrate tasks 
and synchronize undertakings to be completed within a plan scheduled for implementation. Such an approach has a potential synergistic effect strengthening the development opportunities of any projects based on a participatory urban planning idea. It is also important to look at different problems and proposed ideas objectively and comprehensively (yet, it often happens that they are selected at random and separately). The expert has a chance to successfully intermediate between respective groups of participants in the planned investments. Mediating between the groups, the expert shall aspire to balance the proposals on unbiased grounds with the use of an objective decision-making tool. The mixed-method based on both descriptive and normative approaches meets the criteria of participatory urban planning and reinforces the authority of the expert in the process of implementing objectively desirable and socially accepted spatial changes. We hope that the use of this mixed-method by other researchers will allow experiences to be gathered that would result in in-depth scientific discussion and improvement of the developed experimental tool.

\section{ORCID}

Bartosz Kaźmierczak (1) https://orcid.org/0000-0001-8436-6963 Sławomir Palicki (10) https://orcid.org/0000-0003-3410-8039

\section{References}

Arrow, KJ 1963, Social choice and individual values, J. Wiley, New York.

Bell, DE, Raiffa, H \& Tversky, A 1988, Decision making: Descriptive, normative, and prescriptive interactions, Cambridge University Press, Cambridge.

Basheleishvili, I 2020, 'Developing the expert decision-making algorithm using the methods of multi-criteria analysis', Cybernetics and Information Technologies, vol. 20, no. 2, pp. 22-29.

Boryczka, EM, Plesińska, K, Rzeńca, A \& Skórzak, B 2017, 'Diagnozowanie potrzeb lokalnych w programie rewitalizacji. Przykład miasta i gminy Uniejów' ['Diagnosing local needs in the revitalization programme. An example of the city and commune of Uniejów'], Biuletyn Uniejowski, vol. 6, pp. 65-80.

Carmona, M, Tiesdell, S, Heath, T \& Oc, T 2010, Public places urban spaces the dimensions of urban design, Architectural Press, Elsevier, Burlington.

Cichoń, M \& Walecko, S 2017, ,Zastosowanie wybranych narzędzi do analizy przyczyn awarii maszyny w przedsiębiorstwie produkcyjnym' ['Application of selected quality tools to increase machine efficiency in a production enterprise'], Proceedings of the Industry 4.0 and Management and Production Engineering conference. Available from: <ptzp. org.pl>. [23 June 2020].

Dąbrowski, A, Schumann, A \& Woleński, J 2015, Podejmowanie decyzji: pojęcia, teorie, kontrowersje [Decision making: concepts, theories, controversies], Copernicus Center Press, Kraków.

Durka, W 2011, 'Społeczne efekty konsultacji społecznych' ['Social effects of social consultations'] in Przeprowadzanie konsultacji społecznych w samorządzie [Conducting social consultations in local government], Instytut Rozwoju Regionalnego, Szczecin, p 7-11.

Forester, J 1999, The deliberative practitioner, encouraging participatory planning processes, MIT Press, Cambridge.

Grabowski, W 2019, Modele wielopoziomowe. Wykorzystanie danych regionalnych $w$ badaniach mikroekonomicznych $i$ socjologicznych [Multilevel models. Using of regional data in microeconomic and sociological research], Wydawnictwo Uniwersytetu Łódzkiego, Łódź.

Grzybowski, A 2012, Matematyczne modele konfliktu. Wykłady z teorii gier i decyzji [Mathematical models of conflict. Lectures on game theory and decisions], Wydawnictwo Politechniki Częstochowskiej, Częstochowa.

Hamrol, A \& Mantura, W 1999, Zarządzanie jakością. Teoria i praktyka [Quality management. Theory and practice], Wydawnictwo Naukowe PWN, Poznań.

Jałowiecki, B (ed.) 1992, ,Gra o miasto' [,Game of the city'], Biuletyn Komitet Przestrzennego Zagospodarowania Kraju, vol. 157, Państwowe Wydawnictwo Naukowe, Warszawa.
Juran, JM, 2008, 'Pareto. Lorenz, Cournot Bernoulli, Juran and Others', Critical Evaluations in Business and Management, London \& NewYork.

Kaczorowska, Z \& Staniec, I 2019, 'Klasyfikacja ABC/XYZ w zarządzaniu gospodarką materiałową w przedsiębiorstwie produkcyjnym' ['ABC / XYZ classification in material management in a production company'], Zeszyty Naukowe Politechniki Łódzkiej, Organizacja i zarządzanie, vol. 73, no. 1228, Łódź.

Kahneman, D 2012, Pułapki myślenia. O myśleniu szybkim i wolnym [The traps of thinking. Thinking, Fast and Slow], tłum. P. Szymczak, Media Rodzina, Poznań.

Kazepov, Y, Scott, A \& Silver, H 2010, 'Participation in urban contention and deliberation', International Journal of Urban and Regional Research, vol. 34, no. 3, pp. 453-477.

Kaźmierczak, B, Nowak, M, Palicki, S \& Pazder, D 2011, 'Oceny rewitalizacji. Studium zmian na poznańskiej Śródce' [Revitalization assessments. A study of changes in the Śródka district of Poznań], Wydawnictwo Wydziału Nauk Społecznych UAM, Poznań.

Klijn, E \& Skelcher, Ch 2007, 'Democracy and governance networks: compatible or not?', Public Administration, no. 85(3), pp. 587-608.

Kot, J 2003, Zarządzanie rozwojem gmin a praktyka planowania strategicznego [Commune development management and the practice of strategic planning], Wydawnictwo Uniwersytetu Łódzkiego, Łódź.

Kobryń, A 2014, Wielokryterialne wspomaganie decyzji w gospodarowaniu przestrzenią [Multi-criteria decision supporting in space management], Wydawnictwo Difin, Warszawa.

Langendijk, A 2001, 'Regional learning between variation and convergence: The concept of 'Mixed-land-use' in regional spatial planning in the Netherlands', Canadian Journal of Regional Science, vol. 24, no. 1, pp. 135-154.

Larichev, OI 1999, 'Normative and descriptive aspects of decision making' in Multicriteria Decision Making: Advances in MCDM Models, Algorithms, Theory, and Applications, eds. T Gal, TJ Stewart \& T Hanne, Kluwer Academic Publishers, NorwellDordrecht.

Łaszkiewicz, E 2016, Ekonometria przestrzenna III. Modele wielopoziomowe - teoria i zastosowania [Spatial econometrics III. Multilevel models - theory and applications], Wydawnictwo C.H. Beck, Warszawa.

Meléndez, JW \& Parker, B 2019, 'Learning in participatory planning processes: Taking advantage of concepts and theories across disciplines', Planning Theory \& Practice, vol. 20 , no. 2, pp. 1-8.

Martyniuk-Pęczek, J \& Rembarz, G 2016(a), 'The urban mentoring as a new method of participatory urban planning in Poland', Proceedings of World Multidisciplinary Civil 
Engineering-Architecture-Urban Planning Symposium, Procedia Engineering, vol. 161, pp. 1647-1655.

Martyniuk-Pęczek, J \& Rembarz, G 2016(b), ,Urban mentoring jako nowa technika współpracy w procesie planowania partycypacyjnego' [,Urban mentoring as a new technique of cooperation in the participatory planning process'], Biuletyn Komitetu Przestrzennego Zagospodarowania Kraju, vol. 264, Polska Akademia Nauk, pp. 119-146.

Miessen, M 2010, The nightmare of participation (Crossbench praxis as a mode of criticality), The MIT Press, Cambridge.

Nowak, M 2013, 'Niezrealizowana rewitalizacja jako niedoskonała gentryfikacja. Analiza procesu ożywiania poznańskiej Śródki' [,Unrealized revitalization as imperfect gentrification. Analysis of the process of reviving Poznań Śródka'], Ruch prawniczy, ekonomiczny i socjologiczny, vol. LXXV, no. 3, pp. 229-249.

Palicki, S 2013, 'Rewitalizacja a rynek nieruchomości mieszkaniowych. Przypadek poznańskiej Śródki' [Revitalization and the housing real estate market. The case of Śródka in Poznań], Ruch prawniczy, ekonomiczny i socjologiczny, vol. 75, no. 3, Poznań.

Prusak, A \& Stefanów, P 2014, AHP - analityczny process hierarchiczny. Budowa $i$ analiza modeli decyzyjnych krok po kroku [AHP - analityc hierarchy process: Step by step building and analysing the decision models], Wydawnictwo C.H. Beck, Warszawa.

Przywojska, J 2018, 'Revitalisation Committee - a form of the comanagement of the revitalisation process on the example of the city of Łódź' in Zarządzanie procesem rewitalizacji, Przedsiębiorczość i Zarządzanie, eds. J Przywojska \& Morawski P, Wydawnictwo Społecznej Akademii Nauk, XIX/3/III, Łódź-Warszawa.

Przywojska, J 2019, 'Współzarządzanie i partycypacja społeczna w rewitalizacji' ['Co-management and social participation in revitalization'], Rocznik Lubuski, vol. 45, no. 2. pp. 21-34.

Raiffa, H 1994, 'The prescriptive orientation of decision making. A synthesis of decision analysis, behavioral decision making and game theory' in Decision Theory and Decision Analysis. Trends and Challenges, ed. S Rios, Kluwer Academic Publishers, Boston-Dordrecht-London.

Roy, B 1990, Wielokryterialne wspomaganie decyzji [Multi-criteria decision supporting], WNT, Warszawa.

Selle, K2011, ,GroßeProjekte-nach Stuttgart. Herausforderungen der politischen Kultur' in Methoden räumlicher Planung und partizipative Technologievorausschau - Chancen einer interdisziplinären Anknüpfung?, eds M Rehberg \& A Hoffmann, RaumPlanung, no. 156/157.

Simon, HA 1955, 'A behavioral model of rational choice', The Quarterly Journal of Economics, vol. 69, no. 1, pp. 99-118.

Stachowiak, K 2002, 'Wielokryterialna analiza decyzyjna w badaniach przestrzenno-ekonomicznych' ['Multi-criteria decision analysis in spatial-economic research'] in Możliwości i ograniczenia zastosowań metod badawczych w geografii społeczno-ekonomicznej $i$ gospodarce przestrzennej [Possibilities and limitations of the application of research methods in socio-economic geography and spatial management], ed. H Rogacki, Bogucki Wydawnictwo Naukowe, Poznań, pp. 127-136.

Śleszyński, J 1990, 'Gospodarowanie zasobami środowiska przyrodniczego.Problemwielokryterialnościpodejmowanych decyzji' [Management of natural environment resources. The problem of multi-criteria decision making], Biuletyn KPZK PAN, vol. 151, PAN, Warszawa.
Sutton, SE \& Kemp, SP 2006, 'Integrating social science and design inquiry through interdisciplinary design charrettes: An approach to participatory community problem solving', American Journal of Community Psychology, vol. 38, no. 1-2, pp. $125-139$.

Theiss, M, 2013, 'Perspektywa sieci społecznych w badaniach lokalnej polityki społecznej' ['The perspective of social networks in local social policy research'], Problemy Polityki Społecznej. Studia i Dyskusje, vol. 22, no. 3, Instytut Polityki Społecznej Uniwersytetu Warszawskiego, Warszawa, pp. 99-114.

Tversky, A \& Kahneman, D 1981, 'The framing of decisions and the psychology of choice', Science, vol. 211, no. 4481, pp. 453-458.

Wilson, R 1996, Introduction to Graph Theory. Fourth edition, Longman, London.

Wota, AK 2008, Optymalizacja wyboru lokalizacji składowiska odpadów komunalnych $z$ wykorzystaniem metody AHP [Optimizing the choice of a municipal waste landfill location using the AHP method], Wydawnictwo Instytutu Gospodarki Surowcami Mineralnymi i Energią PAN, Kraków.

Vischer, JC 1985, 'The adaptation and control model of user needs: A new direction for housing research', Journal of Environmental Psychology, vol. 19, no. 5, pp. 85-93. 